\title{
5-シクロヘキサデセノンの合成
}

\author{
須賀恭一・渡辺昭次 - 藤田力 五味哲夫 \\ 千葉大学工学部工業化学科 (千菜市弥生町 1 番)
}

\section{Synthesis of 5-Cyclohexadecenone}

\author{
Kyöichi Suga, Shōji Watanabe, Tsutomu Fujita and Tetsuo Gomi \\ Department of Applied Chemistry, Faculty of Engineering, Chiba University (Yayoicho, Chiba)
}

\begin{abstract}
5-Cyclohexadecenone, having musk-like odor, is prepared from cyclododecanone via four new steps; chlorination, Grignard reaction with vinylmagnesium chloride and rearrangement with aluminium isopropoxide, revinylation with vinylmagnesium chloride and oxy-Cope rearrangement. $5-\mathrm{C}$ yclohexadecenone is also prepared from cyclododecane epoxide by the combination of vinylation and chromic oxidation.
\end{abstract}

\section{1 緒 言}

大環状ケトンのあるものはムスク様香気を有してい る。そのため大環状ケトンの合成法については従来多数 の報告があるが，近時有機金属錯体を用いるブタジエン の環化三量化により $1 ， 5 ， 9$-シクロドデカトリエン, シクロドデカノンなどの 12 員環化合物が容易に得られ るようになってから, これらを出発原料とするムスク様 化合物の合成研究がさかんになってきた。たとえば Ohloff ${ }^{1)}$, Eschenmoser ${ }^{2)}$, Nozaki ${ }^{3)}$, Cookson ${ }^{4)}$ らはイ グザルトン，ムスコンなどを合成している。著者らは容 易に入手できるシクロドデカノン (I), シクロドデセ ンエポキシド (XII) を出発物質としてムスク様香気を持 つ新しい大環状ケトンである5-シクロへキサデセノン を合成できたのでここに報告する。

\section{2 実験}

\section{$2 \cdot 1 \quad 2$-クロルシクロドデカノン $(\mathbf{I I})$}

精製シクロドデカノン ( I ) $(72.8 \mathrm{~g}, 0.4 \mathrm{~mol})$, エタ ノール $(450 \mathrm{ml})$, 塩素酸カリウム $8.2 \mathrm{~g}, 0.067 \mathrm{~mol})$ の混合物に, 室温で空素ガスふんい気下精製塩素ガスを ゆっくりと通じた。反応の進行をガスクロマトグラフィ 一 [カラム : Silicone DC-200 (25\%)+Celite 545, 3 m ; 温度 $\left.230^{\circ} \mathrm{C}\right]$ でチェックし, 塩素化が終わったところ でイソプロピルエーテルで抽出し, エーテル溶液は水洗 後無水硫酸ナトリウムで乾燥した。エーテルを留去した 残留油減圧蒸留して2-クロルシクロドデカノン (II) $89.9 \mathrm{~g}$ （ガスクロマトグラフィーによる純度 93\%)を 得た。このものはアセトンで再結晶して精製した。 $\mathrm{mp}$ $57^{\circ} \mathrm{C}$ (文嗝值 $\left.60^{\circ} \mathrm{C}\right)^{6)}$ 。

\section{$2 \cdot 2$ 2-クロルシクロドデカノン（II） より 2-ビニル シクロドデカノン (IV) の合成}

窒素ふんい気下 $-30^{\circ} \mathrm{C}$ で 2 -クロルシクロドデカ, ン $89.5 \mathrm{~g}$ (純度 $93 \% ， 0.385 \mathrm{~mol}$ ) のテトラヒドロフ ラン溶液 $(180 \mathrm{ml})$ にビニルマグネシウムクロリド $(0.5$ $\mathrm{mol})$ のテトラヒドロフラン溶液 $(150 \mathrm{~m} l)^{7)}$ を河っくり と加えた。 $-30^{\circ} \mathrm{C} に 2 \mathrm{hr}$ かくはんしたのちに, $30^{\circ} \mathrm{C}$ でテトラヒドロフランを減圧下留去し, 残留油をジクロ ルメタン $300 \mathrm{~m} l$ に溶解し, ついでアルミニウムトリイ ソプロポキシド $25.6 \mathrm{~g}(0.126 \mathrm{~mol})$ を加えた。反応混 合物を $2 \mathrm{hr} 50^{\circ} \mathrm{C}$ に加熱したのち塩化アンモニウム水 溶液で分解しイソプロピルエーテルで抽出した。エーテ ル溶液は水洗後乾燥した。エーテルを留去した残留油を 減圧蒸留して bp $115 \sim 130^{\circ} \mathrm{C} / 3 \mathrm{mmHg}$ の留分 $82.2 \mathrm{~g}$ を得た。ガスクロマトグラフ分析 [カラム：シリコン DC-200+Celite $545(3 \mathrm{~m})$; 温度 $\left.230^{\circ} \mathrm{C}\right]$ は, このも のが 2-ビニルシクロドデカノン (IV) $\quad(59 \%) \quad\left(R_{t} 17\right.$ $\mathrm{min}), 2$-クロルシクロドデカノン (II) (38\%) ( $R_{t} 19$

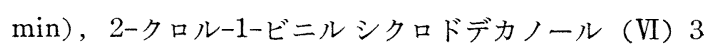
\%) ( $\left.R_{t} 31 \mathrm{~min}\right)$ の混合物であることを示した。化合物 (IV) はシリカゲルを用いるカラムクロマトグラフィー でベンゼンを用いて単離することができ，次のスペクト ルデーターを示した。IR $\left(\mathrm{cm}^{-1}\right): 3080,1710,990,915$; $\mathrm{NMR}(\delta, \mathrm{ppm})\left(\mathrm{CCl}_{4}\right): 1.3\left(s, 18 \mathrm{H}\right.$, ring- $\left.\mathrm{CH}_{2}-\right)$, $2.4\left(t, 2 \mathrm{H},-\mathrm{CH}_{2}-\mathrm{CO}-\right), 3.3\left(\mathrm{~m}, 1 \mathrm{H},-\mathrm{CH}_{2}-\stackrel{1}{\mathrm{C}} \mathbf{H}-\mathrm{CH}\right.$ $\left.\left.=\mathrm{CH}_{2}\right), 4.9 \sim 6.0 \mathrm{~m}, 3 \mathrm{H},-\mathrm{CH}=\mathrm{CH}_{2}\right)$ 。分析值: C, $80.59 ; \mathrm{H}, 12.04 \% . \mathrm{C}_{14} \mathrm{H}_{24} \mathrm{O}$ としての計算值 : $\mathrm{C}, 80.71$ ; H, 11.61\%。

$2 \cdot 3 \quad 1,2$-ジビニルシクロドデカン-1-オール $(\mathbf{V})$ 2-ビニルシクロドデカノン (IV) $17.8 \mathrm{~g}(0.077 \mathrm{~mol})$ 
のテトラヒドロフラン $(40 \mathrm{~m} l)$ 溶液にビニルマグネシ ウムクロリド $(0.3 \mathrm{~mol})$ のテトラヒドロフラン溶液 $(135 \mathrm{~m} l)$ を $-30^{\circ} \mathrm{C}$ で窒素ふんい気下 $6 \mathrm{hr}$ で滴下し た。 $3 \mathrm{hr}$ かくはん後, 塩化アンモニウム水溶液で加水分 解し常法通り処理して bp $150^{\circ} \sim 160^{\circ} \mathrm{C} / 4 \mathrm{mmHg}$ の化合 物 (V) $12.7 \mathrm{~g}$ (純度 $90 \%$ ) を得た。このものはシリ カゲルを用いるカラムで液体クロマトグラフィーを行い $n$-ヘキサン一酢酸エチル $(90: 10)$ 混合溶媒から純粋な （V）を単離することができた。このものは次のスペク トルデー夕を示した。IR：3500, 3050，1420，990，910； NMR : 1.35 (broad $s, 20 \mathrm{H}$, ring- $\left.\mathrm{CH}_{2^{-}}\right), 2.1(m, 1 \mathrm{H}$, $\left.-\mathrm{CH}_{2}-\stackrel{\mathrm{C}}{\mathrm{C}} \mathrm{H}-\mathrm{C}=\mathrm{C}\right), 4.7(\mathrm{~s}, 1 \mathrm{H}, \mathrm{OH}), 4.8 \sim 5.8(\mathrm{~m}$, $\left.6 \mathrm{H},-\mathrm{CH}=\mathrm{CH}_{2}\right) ; \mathrm{MS}(m / e): \mathrm{M}^{+}=236$ 。分析值 : C, $79.33 ; \mathrm{H}, 13.24 \% 。 \mathrm{C}_{16} \mathrm{H}_{28} \mathrm{O}$ としての計算值 : $\mathrm{C}, 79.16$ ; $\mathrm{H}, 13.29 \%$ 。

$2 \cdot 4$ 2-クロル-1-ビニルシクロドデカン-1-オール (VI)

窒素ふんい気下， $-30^{\circ} \mathrm{C}$ で 2-クロルシクロドデカ， ン (II) $22 \mathrm{~g}(0.1 \mathrm{~mol})$ にビニルマグネシウムクロリド $(0.20 \mathrm{~mol})$ のテトラヒドロフラン溶液を滴下した。反 応混合物は常法通り処理して粗結晶 $36.6 \mathrm{~g}$ を得た。こ のものをアセトンから再結晶して純粋の 2-クロルー1-ビ ニルシクロドデカン-1-オール (VI) $19.6 \mathrm{~g}$ (収率 80\%) を得た。 $\mathrm{mp} 44^{\circ} \sim 46^{\circ} \mathrm{C}$; IR : $3500,3080,1640,1410$, 1155, 995, 920; NMR:1.35(broad $s, 16 \mathrm{H}$, ring- $\mathrm{CH}_{2}-$ ), $1.4 \sim 2.0\left(m, 4 \mathrm{H},-\mathrm{CH}_{2}-\mathrm{C}-\mathrm{OH},-\mathrm{CH}_{2}-\mathrm{CHCl}\right), 2.6(s$, $1 \mathrm{H},-\mathrm{OH}), 4.1(t, 1 \mathrm{H},-\mathrm{CHCl}), 5.0 \sim 6.2(m, 3 \mathrm{H}$, $\left.-\mathrm{CH}=\mathrm{CH}_{2}\right)$; 分析值 : C, 69.05; $\mathrm{H}, 9.87 ; \mathrm{Cl}, 15.11 \%$; $\mathrm{C}_{14} \mathrm{H}_{25} \mathrm{OCl}$ としての計算值: $\mathrm{C}, 68.69 ; \mathrm{H}, 10.29 ; \mathrm{Cl}$, $14.48 \%$ 。

\section{$2 \cdot 5$ 5-シクロヘキサデセノン（VII）}

1,2 -ジビニルシクロドデカン-1-オール (V) $(0.70 \mathrm{~g})$ $(3.0 \mathrm{mmol})$ ) ウンデカン $(6.0 \mathrm{~g})$ の混合物を $200^{\circ} \mathrm{C}$ に $4 \mathrm{hr}$ 加熱した。ウンデカンを留去したのち残留油をポッ トスチルを用いて分子蒸留して $80^{\circ} \sim 100^{\circ} \mathrm{C} / 10^{-1} \mathrm{mmHg}$ で蒸発した 5-シクロへキサデセノン (VII) $0.50 \mathrm{~g}$ (収 率 57\%) を得た。このものはシリカゲルを用いるカラ ムクロマトグラフィーで酶酸エチルを用いて純粋にする ことができ，次のスペクトルデータを示した。IR： 1715, 1405, 965 ; NMR : $1.3\left(s, 18 \mathrm{H}\right.$, ring- $\left.\mathrm{CH}_{2^{-}}\right), 1.6$ $\left(m, 4 \mathrm{H}, \quad \mathrm{CH}_{2}-\mathrm{C}=\mathrm{C}-\mathrm{CH}_{2}-\right), 2.3\left(t, 4 \mathrm{H},-\mathrm{CH}_{2}-\mathrm{CO}-\right.$ $\left.\mathbf{C H}_{2^{-}}\right), 5.25(m, 2 \mathrm{H},-\mathrm{CH}=\mathrm{CH}-) ; \mathrm{MS}: \mathrm{M}^{+}=236$ 。分 析值: C, $79.42 ; \mathrm{H}, 13.27 \%$ 。 $\mathrm{C}_{16} \mathrm{H}_{28} \mathrm{O}$ としての計算鲜 : C, $79.16 ; \mathrm{H}, 13.29 \%$ 。

化合物（V) のオキシコープ転位反応を封管中および 開管中無溶媒で行ったが，化合物（VII）の収率はそれぞ れ 16\%，5\% であった。

$2 \cdot 6$ iービニル-1,2-エポキシーシクロドデカン（VIII）
2-クロル-1-ビニルシクロドデカン-1-オール(VI) 5.25 $\mathrm{g}(0.022 \mathrm{~mol})$ をベンゼン汇溶解し $10 \%$ 水酸化ナトリウ 么水溶液 $10 \mathrm{~m} l$ を加え $120^{\circ} \mathrm{C}$ で約 $7 \mathrm{hr}$ かくはんした。 その後, 常法通り処理し, $4.5 \mathrm{~g}$ の粗製の化合物 (III) (純度 80\%) を得た（収率 79\%)。IR：3080，1640， 1410, 1260, 990, 920 ; NMR : 1.4 (broad $s, 18 \mathrm{H}$, ring- $\left.\mathrm{CH}_{2}-\right), 1.9\left(t, 2 \mathrm{H},-\mathrm{CH}_{2}-\stackrel{-}{\mathrm{C}}-\mathrm{CH}-\right), 2.9(t, 1 \mathrm{H}$,

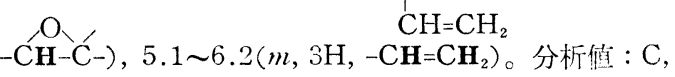
$80.59 ; \mathrm{H}, 11.73 \%$ 。 $\mathrm{C}_{14} \mathrm{H}_{24} \mathrm{O}$ としての計算值 : $\mathrm{C}$, $80.71 ; \mathrm{H}, 11.61 \%$ 。

\section{$2 \cdot 7$ 2-エチリデンシクロドデカノン $(\mathrm{IX})$}

1-ビニルー1,2-エポキシシクロドデカン (VIII) $3.6 \mathrm{~g}$ (0.0173 mol) にジメチルスルホキシド $10 \mathrm{ml}$, 三フッ化 ホウ素エーテラート 5 滴を加え, かくはんしつっ $7.5 \mathrm{hr}$ $90^{\circ} \mathrm{C}$ に加熱した。反応混合物を大量の水水汇加え下か らクロロホルムで抽出し, 常法通り処理して粗製の化合 物 (IX) $3.2 \mathrm{~g}$ を得た(収率 83\%)。これをシリカどルを 用いた液体クロマトグラフィーによってベンゼンージク ロルメタン $=7: 3$ の混合溶媒を用いて (IX) 精製影離 した。(IX) は次のスペクトルデータを示し，その斠造が 確認された。IR : 3050, 1670; NMR : 1.25 (broad $s$, $16 \mathrm{H}$, ring $\left.-\mathrm{CH}_{2}-\right), 1.85\left(d, 3 \mathrm{H},=\mathrm{CH}-\mathrm{CH}_{3}\right), 2.5(m, 4$ $\mathrm{H},-\mathrm{CH}_{2}-\mathrm{CO}-$ および $\left.-\mathrm{CH}_{2}-\mathrm{C}=\mathrm{C}-\right), 6.55\left(q, 1 \mathrm{H}, \mathrm{CH}_{3}\right.$ $-\mathrm{CH}=\mathrm{C}) ; \mathrm{MS}: \mathrm{M}^{+}=208$ 。分析值 : C, 79.88; H, 12.80 $\% 。 \mathrm{C}_{14} \mathrm{H}_{24} \mathrm{O}$ としての計算值：C, 80.71; H, 11.61\%。

2.8 2-エチリデンシクロドデカノン $(\mathbf{I X})$ とビニル マグネシウムクロリドの反応

2-エチリデンシクロドデカノン (IX) $41.6 \mathrm{~g}$ (0.2 mol) とビニルマグネシウムクロリド $(0.4 \mathrm{~mol})$ のテトラヒ ドロフラン溶液を $00^{\circ} \mathrm{C}$ で常法通り反応させた。一晚放 置後, 塩化アンモニウム水溶液で加水分解した。常法通 り処理後減圧蒸留して次の留分を得た。留分 (i) : bp $\sim 123^{\circ} \mathrm{C} / 3 \mathrm{mmHg}$, 收量 $28 \mathrm{~g}$; 留分 (ii) $: \mathrm{bp} 123^{\circ} \sim$ $125^{\circ} \mathrm{C} / 3 \mathrm{mmHg}$, 収量 $10 \mathrm{~g}$; 貿分 (iii) : bp 125 135 ${ }^{\circ} \mathrm{C} / 3 \mathrm{mmHg}$, 収量 $8 \mathrm{~g}$; 残留物: 収量 $2 \mathrm{~g}$ 。留分 (i) 㳉 末変化の (IX), 留分 (ii), (iii) は (X) がそ礼ざれ主: 成分であった。留分 (iii) より分取ガスクロマトグラフ イーにより純䊀な 2-( $\left(1^{\prime}-フ ゙ テ ン-3^{\prime}\right.$-イル)ーシクロドデカ ノン $(X)$ を単離した。このものは次の諸性質を示した。 bp $130^{\circ} \sim 140^{\circ} \mathrm{C} / 3 \mathrm{mmHg}$; IR : 1705, 990, 915; $\mathrm{NMR}$ : $1.0\left(d, 3 \mathrm{H}, \mathrm{CH}_{3}-\mathrm{CH}-\right), 2.5$ (broad, $4 \mathrm{H},-\mathrm{CH}_{2}-\mathrm{CO}$ $-\mathrm{CH}-$ 贴よび $\left.-\stackrel{\mathrm{C}}{\mathrm{C}} \mathbf{H}-\mathrm{CH}=\mathrm{CH}_{2}\right), \quad 1.4(s, 18 \mathrm{H}$, ring $\left.-\mathrm{CH}_{2}-\right), 4.8 \sim 5.5\left(m, 3 \mathrm{H},-\mathrm{CH}=\mathrm{CH}_{2}\right)$; 分析徝: $\mathrm{C}$, $79.15 ; \mathrm{H}, 12.94 \% 。 \mathrm{C}_{14} \mathrm{H}_{28} \mathrm{O}$ としての計算値 : C, 79.18 ; H, 13.29\%。

化合物 (XX) と他の二, 三のグリニャール試薬り反応 を訊みたが，いずれもグリニャール試薬の 1,4 -付加物 
Table-1 The reaction of 2-ethyliden-cyclododecanone (IX) with various Grignard reagents.

\begin{tabular}{c|c|c|c}
\hline $\begin{array}{c}\text { Grignard } \\
\text { reagent } \\
\mathrm{R}-\end{array}$ & $\begin{array}{c}\text { Yield of } \\
\text { product } \\
(\mathrm{X})\end{array}$ & $\begin{array}{c}\text { bp } \\
(\%)\end{array}$ & $\begin{array}{c}\text { Yield of 1,4- } \\
\text { adduct (XI) } \\
(\%)\end{array}$ \\
\hline $\mathrm{C}_{2} \mathrm{H}_{5}-$ & 65 & $105 \sim 110^{\circ} \mathrm{C} / 5 \mathrm{mmHg}$ & 3 \\
$i-\mathrm{C}_{3} \mathrm{H}_{7}-$ & 70 & $120 \sim 125^{\circ} \mathrm{C} / 5 \mathrm{mmHg}$ & 2 \\
$n-\mathrm{C}_{3} \mathrm{H}_{7}-$ & 75 & $125 \sim 130^{\circ} \mathrm{C} / 5 \mathrm{mmHg}$ & 2 \\
$n-\mathrm{C}_{4} \mathrm{H}_{9}-$ & 70 & $130 \sim 140^{\circ} \mathrm{C} / 5 \mathrm{mmHg}$ & 2 \\
$\mathrm{C}_{6} \mathrm{H}_{5}-$ & 55 & $170 \sim 180^{\circ} \mathrm{C} / 5 \mathrm{mmHg}$ & 1
\end{tabular}

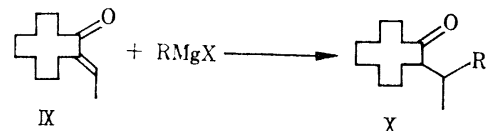

が主反応生成物さして得られた。これらの結果を Table -1 に示す。

2.9 シクロドデセンエポキシド（XII）より 2-ビニ ルシクロドデカン-1-オール (XIII) の合成

シクロドデセンエポキシド (XII) $18.2 \mathrm{~g}(0.1 \mathrm{~mol})$ の テトラヒドロフラン溶液 $(50 \mathrm{ml})$ にビニルマグネシウム クロリド $(0.50 \mathrm{~mol})$ のテトラヒドロフラン溶液 $200 \mathrm{~m} l$ を加え, 窒索ふんい気下約 $30 \mathrm{hr}$ 還流した。塩化アンモ 二ウム水溶液で加水分解し常法通り処理後, 減圧蒸留し て次の留分它得た。留分 (i ) : bp $\sim 90^{\circ} \mathrm{C} / 11 \mathrm{mmHg}$, 収量 $1.1 \mathrm{~g}$; 留分 (ii) : $90^{\circ} \sim 140^{\circ} \mathrm{C} / 11 \mathrm{mmHg}$, 収量 $7.8 \mathrm{~g}$; 留分 (iii) : bp $140^{\circ} \sim 165^{\circ} \mathrm{C} / 6 \mathrm{mmHg}$, 収量 6.7 $\mathrm{g}$; 残留物 8.5g. 留分 (i ) はシクロドデセンその他の 混合物, 留分 (ii) は (XII), 留分 (iii) は (XIII) が主 成分であった。留分 (iii) を精留して純粋な (XII) を 得, 次の性質を示した。bp $105^{\circ} \sim 110^{\circ} \mathrm{C} / 1 \mathrm{mmHg}$; IR : 3450, 3080, 1070, 995, 915; NMR : 1.4 (broad $s, 18 \mathrm{H}$, ring $\left.-\mathrm{CH}_{2}{ }^{-}\right), 1.6 \sim 2.1\left(\mathrm{~m}, 2 \mathrm{H},-\mathrm{CH}_{2}-\stackrel{\mathrm{C}}{\mathrm{C}}-\mathrm{OH}\right), 2.2(\mathrm{~m}$, $\left.1 \mathrm{H}, \mathrm{CH}_{2}-\mathrm{CH}-\mathrm{CH}=\mathrm{CH}_{2}\right), 2.45(s, 1 \mathrm{H}, \mathrm{OH}), 3.65(m$, $\left.1 \mathrm{H}, \mathrm{CH}_{2}-{ }^{\mathrm{C}} \mathbf{H}-\mathrm{OH}\right), 5 \sim 6\left(m, 3 \mathrm{H},-\mathbf{C H}=\mathrm{CH}_{2}\right)$; 分析值: $\mathrm{C}, 80.15 ; \mathrm{H}, 12.51 \%$. $\mathrm{C}_{14} \mathrm{H}_{26} \mathrm{O}$ としての計算值：C, $79.93 ; \mathrm{H}, 12.46 \%$

2.10 2-ビニルシクロドデカン-1-オール（XIII） の 酸化による 2-ビニルシクロドデカノン（IV）の合成

化合物 (XIII) $10.5 \mathrm{~g}(0.05 \mathrm{~mol})$, 水酢酸 $30 \mathrm{ml}$ の混 合物に, 無水ク口ム酸 $4 \mathrm{~g}$, 水酢酸 $22 \mathrm{~m} l$, 水 $2.7 \mathrm{ml}$ の 混合物を $14^{\circ} \mathrm{C}$ でかくはんしつつ約 $1 \mathrm{hr}$ にわたり滴下 した。さらに $2 \mathrm{hr}, 14^{\circ} \mathrm{C}$ でかくはんを続けたのち一夜 放置した。水 $200 \mathrm{~m} l$ を加えイソプロピルエーテルで抽 出した。エーテル溶液を炭酸カリウム水溶液, 水で洗浄 した。常法通り処理し減圧蒸留して次の留分を得た。留 分 (i ) : $120^{\circ} \mathrm{C} / 4 \mathrm{mmHg}$, 収量 $2.4 \mathrm{~g}$; 留分 (ii) $120^{\circ}$ $\sim 132^{\circ} \mathrm{C} / 4 \mathrm{mmHg}$, 収量: $3.0 \mathrm{~g}$; 残留物 $3.0 \mathrm{~g}$ 。留分 (i) は約 40\%, 留分 (ii) は約 20\% の目的物 (VI) を含 んでおり，他の成分は大部分原料の（XII) であった。
化合物 (IV) は留分 (i) より分取ガスクロマトグラフ ィーにより単離し，前述の方法で合成した標準の（JV) と比較して同定した。

\section{3 結 果と考察}

シクロドデカノン（I）からは四式に示す方法で 5シクロヘキサデセノン (VII) を合成した。すなわち（I） を塩素ガスで常法通り塩素化して 2-クロルシクロドデ カノン（II）を收率 97\% で得た。2-クロルシクロドデ

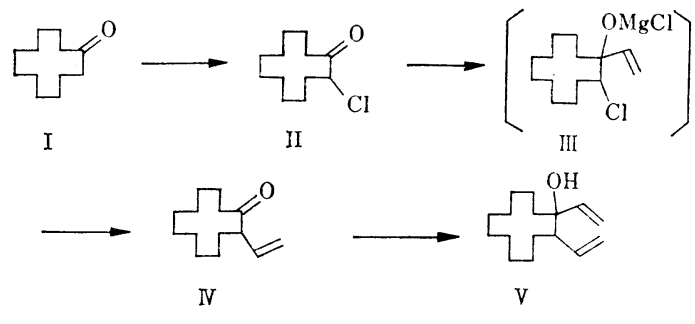

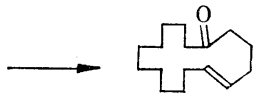

VII

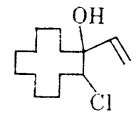

VI
カノン（II）とビニルマグネシウムクロリドの反梞をデ トラヒドロフラン中で行い，得られた中間化合物 (III) を分解することなく直ちにジクロルメタン中でアルミニ ウムイソプロポキシドで処理して 2-ビニルシクロドデ カノン (IV) を収率 $60 \%$ で得た。本反応で化合物 (II) をビニルマグネシウムクロリドで反応させ常法通り加水 分解すると 2-クロルー1-ビニルシクロドデカンー1-オー ル (VI) が $80 \%$ の收率で得られることから，化合物 (III) が化合物 (IV) 生成の中間化合物である上考えられ る。なお，ごく最近，西野らにより著者らとほさんど同 じ方法で化合物 (VII) の合成法が報告され在 ${ }^{5 !}:$ こ方 法によると化合物（II）とビニルマグネシウムクロリド を $0^{\circ} \mathrm{C}$ で反応させついで約 $15 \mathrm{hr} 55^{\circ} \mathrm{C}$ に加熱すると一 段階の反応で化合物 (V) が約 $40 \%$ の収率で得られる し報告している。著者らは化合物 (IV) を常法通りビ二 ル化して 1,2-ジビニルシクロドデカン-1-オール (V) とし，（V）をウンデカン中で熱コープ际位こ行ってム スク様香気を有する5-シクロヘキサデセノン（III）在合 成した。(VI) は IR, NMR, MS などによりそつ構造を 確認した。

目的物 (VII) 合成の中間化合物 (IV) 在得吉心心， (II) とビニルマグネシウムクロリドから得た (V) を脱 塩酸して 1-ビニル-1，2-エポキシシクロドデカン (III) とし，(VII）を異性化して（IV）を合成しょう之軾みた が，(IIII）の異性化ではビニル基の二重結合が共役の位. 置に移った 2-エチリデンシクロドデカノンが(IX) 主性 成物として得られた。この化合物き(IX) にビニルマグネ 


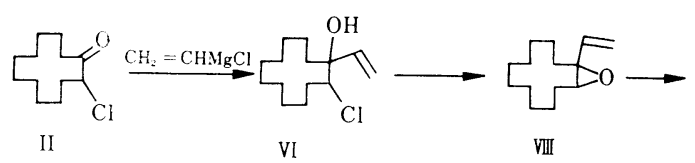

VI

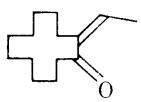

IX

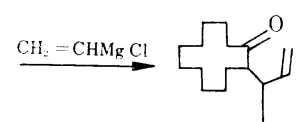

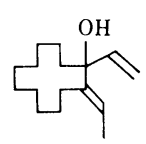

XI
シウムクロリドを付加させてアルコール体（XI）をつく り，ついで閉環して新しい環状化合物を合成しようと試 みたが，(IX) とビニルマグネシウムクロリドの反応で は 1,4-付加したよ考えられる 2-(1'-ブテン-3'-イル) -1-シクロドデカノン (X) が主反応生成物として得ら れ，1,2-付加物の（XI）はほとんど得られなかった。他 のグリニャール試薬を用いても主反応生成物は (X) と 同様に1,4一付加物のケトン体であった。

シクロドデセンエポキシド (XII) からも図式の方法で

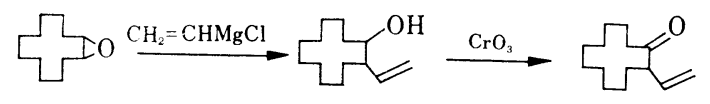

XII
5-シクロヘキサデセノン（VII）の合成を試みた。すなわ ち 2-ビニル-1-シクロドデカノール (XIII) は (XII) とビ ニルマグネシウムクロリドとをテトラヒドロフラン中で 還流することによって得た。ついで（XIII）の無水ク口 ム酸による酸化によって低收率ではあるが (IV) を得る ことができた。この（IV）をビニル化後，前と同様にし て化合物（VII）に導くことができた。

(昭和 49 年 1 月 22 日受理)

\section{文献}

1) G. Ohloff, J. Becker, K.H. Schlte-Elte, Helv. Chim. Acta, 50, 705 (1967)

2) A. Eschenmoser, D. Felix, G. Ohloff, Helv. Chim. Acta, 50, 708 (1967)

3) H. Nozaki, H. Yamamoto, T. Mori, Can. J. Chem., 47, 1107 (1969)

4) R.C. Cookson, P. Singh, J. Chem. Soc. (C)., 1477 (1971)

5) M. Nishino, H. Kondo, A. Miyake, Chem. Letters, No. 7, 667 (1973)

6) Belg. 622,059, Dec. 28, 1962; Chem. Abstr., 60, 1618 b (1964)

7) H. Normant, "Advances in Organic Chemistry, Method and Results", Vol. II, p. 1(1960), Interscience, New York 